\title{
Organic Compost of Swine Manure in the Production of Green Corn in Manaus, Brazil
}

\author{
Pamela Karoline Correia Brunner ${ }^{1}$, Hugo César Tadeu ${ }^{2}$, Carla Coelho Ferreira ${ }^{3}$, Ana Cecília Nina Lobato ${ }^{3}$, \\ Aurinei da Silva Ramos ${ }^{3} \&$ Albejamere Pereira de Castro ${ }^{3}$ \\ ${ }^{1}$ Faculty of Agricultural Sciences, Federal University of Amazonas, Manaus, Brazil \\ ${ }^{2}$ Experimental Farm, Federal University of Amazonas, Manaus, Brazil \\ ${ }^{3}$ Postgraduate Program in Tropical Agronomy, Federal University of Amazonas, Manaus, Brazil \\ Correspondence: Carla Coelho Ferreira, Programa de Pós-graduação em Agronomia Tropical, Universidade \\ Federal do Amazonas, Manaus, Brazil. Tel: 55-92-99603-7995. E-mail: carlacoelhofigueiredo@gmail.com
}

Received: January 13, 2020

doi:10.5539/jas.v12n10p188

\author{
Accepted: August 13, $2020 \quad$ Online Published: September 15, 2020 \\ URL: https://doi.org/10.5539/jas.v12n10p188
}

\begin{abstract}
Pig farming is considered one of the activities with the greatest environmental impact due to the erroneous disposal of swine waste. The present work aimed to produce an organic compost using waste from pig production and evaluate its chemical characteristic, corn yield under doses of this organic compost and soil nutritional quality before and after the experiment implementation. The Corn was fertilized at sowing and 30 days after plant germination using organic compost from pig waste at the doses: $0,2,3,4$ and $5 \mathrm{tha}^{-1}$. The Corn used was CATIVERDE 02 and were seeded at $1.0 \mathrm{~m}$ spacing between rows and $0.40 \mathrm{~m}$ between plants, in a total area of $240 \mathrm{~m}^{2}$. The experimental design was randomized blocks with four replications and five doses of organic compost. The parameters evaluated for corn were: plant height, stem diameter, weight and corncob length. Fertilization with swine organic compost increases in soil P, K, Ca, even after the corn harvest. The best treatment was with a dose of $5 \mathrm{tha}^{-1}$, as it resulted in higher plant height $(1.85 \mathrm{~m})$ and corn cob weight $(261 \mathrm{~g})$.
\end{abstract}

Keywords: Zea mays L., composting, nutrients, organic fertilization

\section{Introduction}

The expansion of pig farming in Brazil has the concentration of confined animals in small areas as the main feature, to meet domestic and international consumption, as a consequence, it increases the production of swine manure, these that impact the environment (Cardoso, Oyamada, \& Silva, 2015).

Pig production is one of the activities with the greatest environmental impact, is considered by environmental control agencies as potentially causing environmental degradation. Release of untreated swine effluent into soil, rivers and lakes is a potential risk for the appearance of disease and degradation of natural resources, such as fish and animal death and plant toxicity (Oliveira, Lima, \& Cajazeira, 2004).

The use of materials that are byproducts of agricultural and industrial activities is of great interest, because of its abundance, of the low cost of acquisition and the very difficult of disposing of these materials in the environment (Brandão, Matos, Martinez, \& Fontes, 2000; Tavera-Cortés, Escamilla-García, \& Pérez-Soto, 2018).

Manure is the best known source of organic matter when it comes to organic fertilizers. It is a resource that the farmer has available that should be optimized (Weinärtner, Aldrighi, \& Medeiros, 2006). Swine liquid manure has 3 to $6 \%$ dry matter and can be used as fertilizer, generating greater nutrient cycling for crops. They provide higher nutrient accumulation, such as $\mathrm{P}, \mathrm{K}, \mathrm{Cu}$ and $\mathrm{Zn}$, when compared to mineral fertilization, and their $\mathrm{Cu}$ and $\mathrm{Zn}$ contents present low mobility, reducing the risk of leaching, reducing environmental risks (Scherer, Nesi, \& Massotti, 2010; Lourenzi et al., 2014; Algeri, 2018).

Swine manure can be used for composting liquid manure for its liquid to solid conversion. For the composting of these wastes there is a need for moisture removal, which in this material is approximately $95 \%$, so the processing of swine manure composting differs from the conventional composting process. The evaporation process should be privileged in order to incorporate a large volume of waste into the substrate (Kunz, Higarashi, \& Oliveira, 2005). It is noteworthy that the production system used in the farms defines the degree of manure dilution, thus 
changing the physicochemical characteristics of the fertilizer (Scherer, \& Baldissera, 1994; Dartora, Perdomo, \& Tumelero, 1998).

Among the advantages of using compost: rapid microbial action on organic matter; reduction of odors by fermentation that makes the compound stable; elimination of pathogenic organisms; flexibility of operation; non-contamination of ground and surface water; modification of the physical presentation of swine manure from liquid to solid, favoring its storage and transport. Thus, it represents a viable alternative for the treatment of swine manure, enabling the reduction of the environmental impact of the activity (Pra, Correa, Roll, \& Xavier, 2008).

Efficiency in the supply of $\mathrm{N}$ through swine bedding for corn under no-tillage system system is $50 \%$ lower in relation to the use of liquid swine manure (DSL), however, there are no studies available on the agronomic efficiency of the DSL biofertilizer treated by digestion and composed of swine manure, treated by composting, in Brazil (Giacomini \& Aita, 2008; Grave, Cassol, Nicoloso, Sordi, \& Costa, 2016).

We chose maize crop to test the efficiency of the organic compost from swine waste for its socioeconomic importance. Besides the economic importance of corn grains and seeds, the corn plant can be used for silage production. In addition, the straw, cob, whole cob and ends of the cob can be crushed and supplied fresh or ensiled, being a high-quality roughage, minimizing feed expenses (Costa, 2005; Castro Filho, Barbosa, Oliveira, Bagaldo, \& Gastal, 2007). Our objective was to evaluate the productivity and quality of corn under different doses of swine manure organic compost.

\section{Method}

\subsection{Experiment Location}

The experiment was implemented at the Experimental Farm of the Federal University of Amazonas, Manaus, Brazil. The average annual temperature, rainfall and humidity are 25 to $28{ }^{\circ} \mathrm{C}, 2,100 \mathrm{~mm}$ and 84 to $90 \%$, respectively (Ribeiro et al., 1999). Meteorological data were obtained from meteorological station 82331 of the National Institute of Meteorology (Inmet) in the state of Amazonas, from February to May, with average values for maximum temperature, minimum temperature and total precipitation equal to $32{ }^{\circ} \mathrm{C}, 25{ }^{\circ} \mathrm{C}$ and $335 \mathrm{~mm}$, respectively.

\subsection{Organic Compost Production}

In the first phase of composting production, liquid manure and sawdust were weighed on an analytical balance. According to Lazia (2012) for each $1 \mathrm{~kg}$ of sawdust, 10 (L) of pig manure is used, therefore, the need for sawdust and manure was calculated according to the treatment doses. The sawdust was arranged in a bed format, with an area of $2 \times 1$ meters, in a stall. In order to obtain better incorporation of the waste in the sawdust, the application of the waste was carried out in installments, in 4 applications, separated by 15 days, with the material being rotated every two days with a hoe, aiming at the homogenization of the material (Pra et al., 2008). Water was added when the material had a dry appearance.

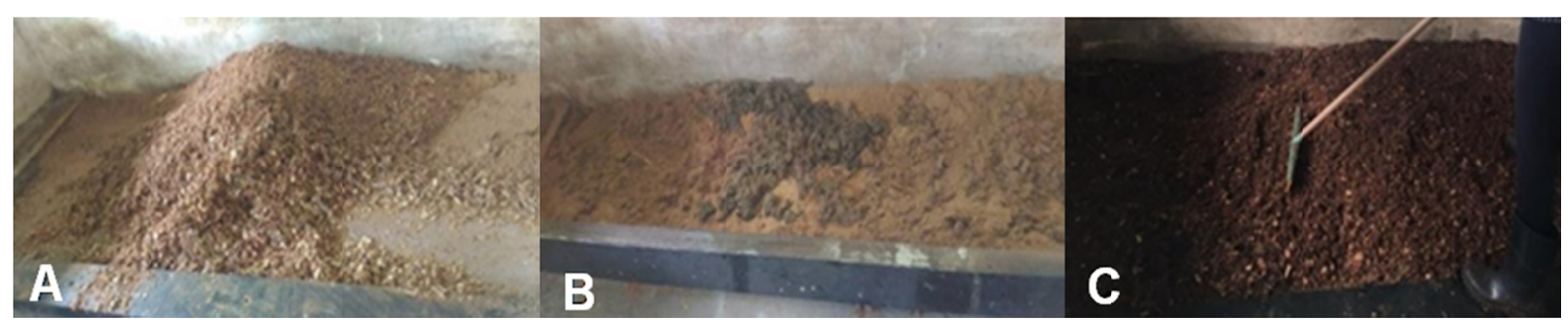

Figure 1. Sawdust used (A); Phase one of organic compost production (B); Phase two of organic compost production $(\mathrm{C})$

Phase two composting lasted 50 days to stabilize the waste to make compost suitable for use in planting. In the end, the organic compost was stored in fiber bags and the chemical analysis was made by the Soil Laboratory of the Federal University of Amazonas from randomly collected $200 \mathrm{~g}$ samples, properly packaged and identified.

\subsection{Preparation of Experimental Area for Corn Cultivation, Fertilization and Planting}

Relative Power of Total Neutralization $=91 \%$ limestone was applied at a dose of $2.62 \mathrm{tha}^{-1}$ at experimental area. After 30 days harrowing and sowing were performed. The doses of organic compost $\left(0,200,300,400,500 \mathrm{~g} \mathrm{~m}^{-1}\right.$ 
equivalent to $0,2,3,4$ and $5 \mathrm{t} \mathrm{ha}^{-1}$ ) were applied manually at the time of planting. Corn seeds of the cultivar CATIVERDE $02,2017 / 2018$ crop, minimum purity of $98 \%$ and minimum germination of $85 \%$, of SELEGRÃOS brand were used.

Two seeds were sown in the soil at a depth of $5 \mathrm{~cm}$ with a spacing of $1.0 \mathrm{~m}$ between rows and $0.40 \mathrm{~m}$ between plants. Thinning was performed, leaving only the most vigorous plant. The border lines were planted between the useful lines for evaluation, obtaining an area of $16 \times 15 \mathrm{~m}^{2}$, totaling 200 plants. The coverage fertilization was performed using the same doses 30 days after germination.

\subsection{Conducting the Experiment and Harvesting}

The development of the plants was observed and registered until the moment of the harvest. Weeding was done when necessary. The green corn was harvested when the grains were in a pasty state, the point of harvest varies according to climatic conditions (Pereira Filho, 2002). All corn cobs of the useful line were collected, identified and packed in a plastic bag for further evaluation.

The following parameters were evaluated: plant height (measured from the ground level, the insertion of the last leaf), stem diameter (obtained at the first internode at the base of the plant), corn cob weight and length.

\subsection{Soil Analysis Before and After the Experiment}

The chemical analysis of the soil before and at the end of the experiment was carried out by the Soil Laboratory of the Federal University of Amazonas. Twenty samples were collected at different points throughout the experimental area, in the $0-20 \mathrm{~cm}$ layer, with the aid of a hoe, the 20 samples were homogenized with the aid of a plastic bucket, and 200 grams of the total sample was packed and properly identified to be sent to the laboratory (Arruda, Moreira, \& Pereira, 2014).

\subsection{Statistical Analysis}

The data were submitted to the F test for variance analysis and regression analysis by SISVAR software. Later, graphs were generated in the Excel program (Ferreira, 2014).

\section{Results}

The chemical characteristics of the organic compost of swine manure were obtained from the same methodology as the soil analysis (Table 1).

Table 1. Chemical characteristics of organic swine manure

\begin{tabular}{|c|c|c|c|c|c|}
\hline MO & $\mathrm{pH}$ & $\mathrm{P}$ & $\mathrm{K}$ & $\mathrm{Ca}$ & $\mathrm{Mg}$ \\
\hline & & \multicolumn{2}{|c|}{ - } & $---\cdot$ & $\mathrm{dm}^{-3}$ \\
\hline 33.5 & 6 & 427 & 1130 & 7 & 5 \\
\hline
\end{tabular}

Note. $\mathrm{MO}=$ Organic Matter; $\mathrm{P}=$ Fósforo; $\mathrm{K}=$ Potássio; $\mathrm{Ca}=$ Cálcio; $\mathrm{Mg}=$ Magnésio.

We evaluated the characteristics of plant height, stem diameter, weight and corn cob length. The doses of organic compost from swine manure affected all parameters except stem diameter that did not present statistical difference (Table 2).

Table 2. ANOVA for the effect of doses of swine manure organic compost in the average of the stem diameter

\begin{tabular}{llllll}
\hline Source & DF & SS & MS & F test & P value \\
\hline Treatments & 4 & 65.45812 & 16.36453 & 3.047 & 0.06 \\
Blocks & 3 & 62.92848 & 20.97616 & 3.906 & 0.037 \\
Error & 12 & 64.44972 & 5.37081 & & \\
Total corrected & 19 & 192.83632 & & & \\
\hline
\end{tabular}

Note. $\mathrm{DF}=$ Degrees of freedom; $\mathrm{SS}=$ Sum of squares; MS = Mean square.

The height of the corn plants presented significant difference as a function of the application of doses of organic compost of swine, presenting as the best treatment the $\mathrm{T} 5-500 \mathrm{~g} \mathrm{~m}^{-1}$ or $5 \mathrm{t} \mathrm{ha}^{-1}$ (Figure 2). 


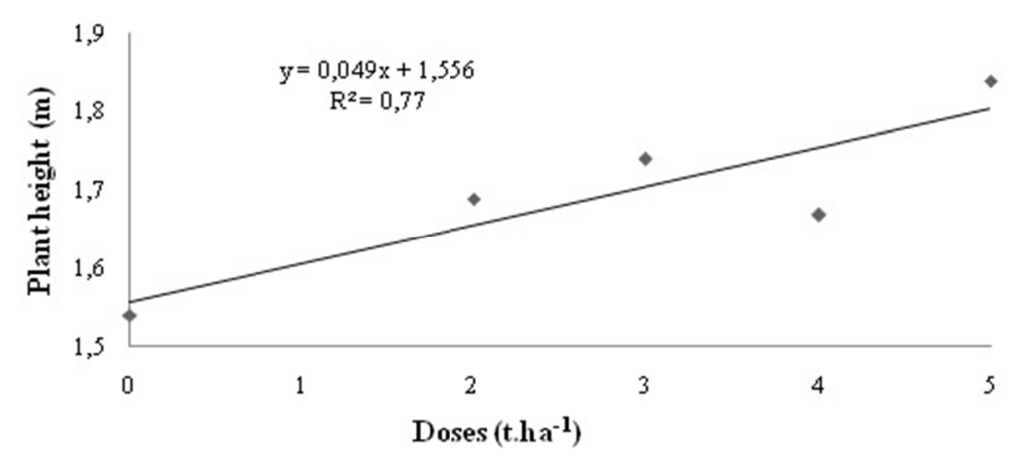

Figure 2. Linear regression graph of the height parameter of maize plants under doses of swine waste compost organic

The weight and corncob length parameters presented significant difference with the application of doses of organic compost of swine, presenting higher values in treatment T5 $\left(5 \mathrm{t} \mathrm{ha}^{-1}\right)$ and T2 $\left(2 \mathrm{tha}^{-1}\right)$, respectively (Figures 3 and 4).

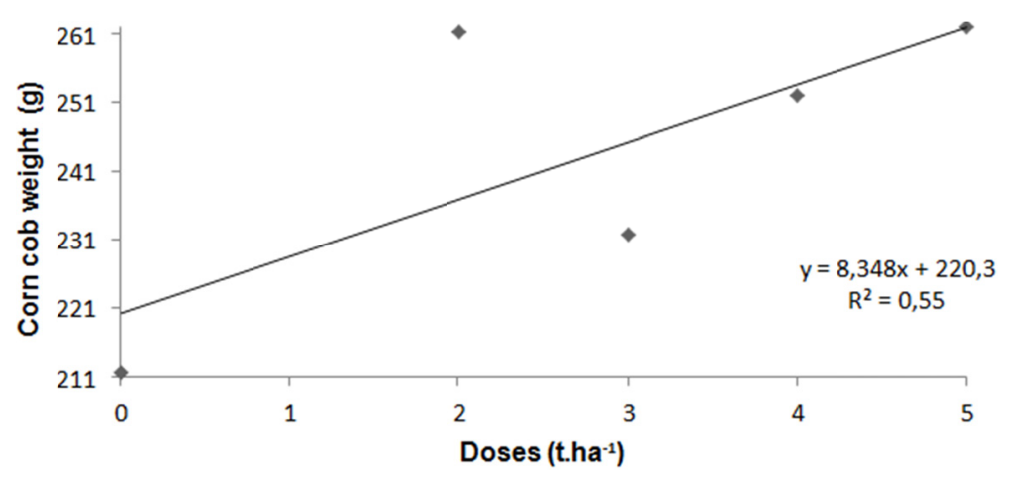

Figure 3. Linear regression graph of corn cob weight parameter under doses of swine waste compost organic

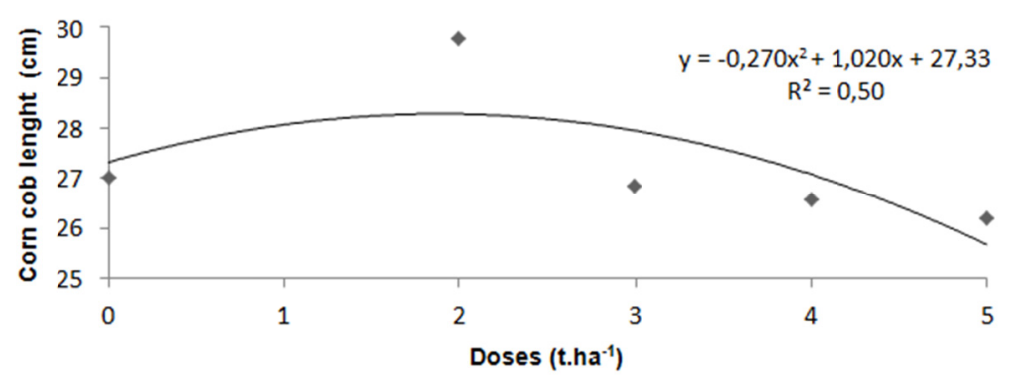

Figure 4. Linear regression graph of corn cob length parameter under doses of swine waste compost organic

The levels of Phosphorus, Potassium, Calcium, besides the $\mathrm{pH}$ and effective CTC values, were higher after the experiment implementation (Tables 3 and 4).

Table 3. Soil chemical characteristics of the total area before experimenting with implementation

\begin{tabular}{|c|c|c|c|c|c|c|c|c|c|}
\hline Depth & $\mathrm{pH}$ & $P$ & $\bar{K}$ & $\mathrm{Ca}$ & $\mathrm{Mg}$ & $\mathrm{H}+\mathrm{Al}$ & TEB & ECEC & BS \\
\hline $\mathrm{cm}$ & & & $\mathrm{dm}^{-3}----$ & --- & -- & cmo & $n^{-3}-$ & & $\%$ \\
\hline $0-20$ & 4.5 & 17 & 46 & 2.6 & 1.4 & 5.2 & 4.12 & 4.42 & 44.2 \\
\hline
\end{tabular}

Note. TEB = Total Exchangeable Bases; ECEC = Effective Cations Exchange Capacity; BS = Base Saturation. 
Table 4. Soil chemical characteristics of the total area after the implementation experiment

\begin{tabular}{|c|c|c|c|c|c|c|c|c|c|}
\hline Depth & $\mathrm{pH}$ & $\mathrm{P}$ & $\mathrm{K}$ & $\mathrm{Ca}$ & $\mathrm{Mg}$ & $\mathrm{H}+\mathrm{Al}$ & TEB & ECEC & BS \% \\
\hline $\mathrm{cm}$ & & \multicolumn{8}{|c|}{---- $\mathrm{mg} \mathrm{dm}^{-3}$} \\
\hline $0-20$ & 5.3 & 27 & 66 & 3.2 & 1.3 & 3.08 & 4.75 & 4.75 & 60.66 \\
\hline
\end{tabular}

\section{Discussion}

According to Cardoso et al. (2015) swine manure is responsible for environmental problems, the main one being groundwater contamination. Among the alternatives adopted in Brazil for the treatments of these wastes are the composting of solid swine waste and the liquid biofertilizer of swine, the latter being the most common. Composting is a technique used on a small scale but gradually growing. There are no studies in the literature related to organic fertilization with solid swine manure on crop yield. Thus, for discussion purposes, works with swine liquid biofertilizer will be approached.

The chemical characteristics of the organic compost of swine manure differed from those found by Seidel et al. (2010), these found higher values in pig liquid fertilizer: $\mathrm{N}=37.91 ; \mathrm{P}=14.81 ; \mathrm{K}=19.32 ; \mathrm{Ca}=66.42 \mathrm{~g} \mathrm{dm}^{-3}$. Considering that for the production of organic fertilizer the methodology of Pra et al. (2008) was used to obtain a solid compost, losses of these nutrients may have occurred, however, the composition of the manure may vary due to factors such as race, feeding and age of animals (Weinärtner et al., 2006).

The stem diameter was not influenced by the different fertilizer doses (Table 2). The same result was found by Castoldi, M. Costa, L. Costa, Pivetta, and Steiner (2011), who evaluated different types of fertilizer, mineral, organic and organomineral in corn plants. Organic fertilization consisted of porcine biofertilizer at a dose of 25 $\mathrm{m}^{3} \mathrm{ha}^{-1}$, and showed no statistical difference.

The stem diameter can be changed according to the plant density in the field. Calonego, Poleto, Domingues, and Tiritan (2011) reported in their maize plant research that the largest number of plants per hectare $(75,000$ plants $\mathrm{ha}^{-1}$ ) promoted the highest plant growth in height, but the values stem diameter were reduced, presenting an average of $6.9 \mathrm{~cm}$. In the present work, 25,000 plants ha $^{-1}$ were obtained, that is, a smaller number of plants per hectare, however the stem diameter values did not present significant results, presenting a lower average (2.32 $\mathrm{cm})$. Fornasieri Filho (2007) mentions that, according to the cultivar used, it may undergo physiological and morphological changes in the plants, causing an increase in bedridden and broken plants, resulting in low grain yield. Thus, as the same spacing and the same cultivar were used throughout this experiment, the absence of statistical difference between treatments for the stem diameter parameter is justified.

The highest dose tested $\left(500 \mathrm{~g} \mathrm{~m}^{-1}\right.$ or $\left.5 \mathrm{t} \mathrm{ha}^{-1}\right)$ resulted in a higher average plant height (Figure 2). This result corroborates the research by Souza, Brito, Fonseca, \& Bebé (2016), in which the height of maize plants was also influenced by the increase of swine liquid fertilizer doses. However, by using the liquid form of manure, the present $\mathrm{N}$ is in mineral form, available for the development of most crops (Serafim \& Galbiatti, 2012), while in the solid fraction $\mathrm{N}$ is part of the organic compounds and becomes if available to plants when undergoing the mineralization process (Pra, Kozen, Oliveira, \& Moraes, 2005). According to Silva and Queiroz (2002), plant height and dry matter production are correlated, becoming an important parameter in crop evaluation.

Cesarino (2006) evaluated five treatments, one chemical and one swine residual liquid (DSL), for the planting of two corn silage hybrids, consisting of the following treatments: T1 $=$ control, T2 $=$ cover chemical fertilizer, T3 = $50 \mathrm{DSL} \mathrm{m}^{3} \mathrm{ha}^{-1}, \mathrm{~T} 4=100 \mathrm{DSL} \mathrm{m}^{3} \mathrm{ha}^{-1}, \mathrm{~T} 5=150 \mathrm{DSL} \mathrm{m}^{3}$.ha $\mathrm{h}^{-1}$. The results for plant height were significant for chemical fertilization and DSL fertilization, with height values between 1.98 and 2.10 meters, while in the present study the height values were lower, between 1.67 and 1.84 meters, possibly due to the maize cultivar used.

Since the spacing used was the same for all treatments, there was probably an increase in $\mathrm{N}$ supply with increasing dose of swine manure compost resulting in height increase, as this nutrient plays a role in vegetative growth (Malavolta, 2006).

Nitrogen stands out in relation to the nutrients required by corn, besides being absorbed in greater quantity is also the most limiting. It has structural function, being part of molecules of organic compounds and acts as activator of many enzymes, also participates in processes such as protein synthesis, ionic absorption, photosynthesis, respiration, multiplication and cell differentiation that stimulate the rapid growth of plants and other characteristics directly or indirectly affecting crop productivity. Thus, proper management of $\mathrm{N}$ sources and 
doses will influence crop response to fertilization (Marschner, 1995; Malavolta, 2006; Okumura, Mariano, \& Zaccheo, 2011).

The corn cob weight and length parameters presented higher values in treatment T5 $\left(5 t^{-1} a^{-1}\right)$ and T2 $\left(2 t_{h a}^{-1}\right)$, respectively (Figures 3 and 4). Differing from the research by Castro and Coelho (2014), they found that the use of organic fertilizer containing star grass, swine manure and shavings in doses of 2.2, 3.2, 4.34 and $5.4 \mathrm{tha}^{-1}$ did not influence the weight and length of corn cobs.

Nakano Neto and Melo (2010) evaluated maize under different sources of fertilization, including $7.5 \mathrm{t} \mathrm{ha} \mathrm{a}^{-1}$ of swine bed overlapping, where the present study diverges with the results found by them, since there was no significant difference for the corn cob weight, even when compared to chemical fertilization.

Differences in the results of research on liquid biofertilizer and organic swine manure compost can be explained by different manure compositions. Because it varies according to the rearing system employed, the type of feeding, age of the animals and the amount of water in the composition of the manure. One of the factors responsible for the low concentration of nutrients is the large dilution of manure in water, caused by the high amount used in the sanitation of facilities (Oliveira, 1993, 2004).

The increase in the weight and length of the corn cobs as a function of the increase of the doses in the swine manure treatments may be a result of the potassium and phosphorus contents present in the fertilizer. The number of ovules in the corn cob and its size are influenced by the environment and can be reduced in case of deficiencies in the amount of water and nutrients $(\mathrm{N}, \mathrm{P}, \mathrm{K}, \mathrm{Ca}$ and $\mathrm{Mg}$ ) to meet plant requirements (Magalhães \& Durães, 2006).

According to Coelho (2006) the highest demand for maize in relation to nutrients is nitrogen and potassium, followed by calcium, magnesium and phosphorus and the export of these nutrients to grains is respectively: 70 to $77 \%, 26$ to $43 \%, 3$ to $7 \%, 47$ to $69 \%$ and 77 to $86 \%$. Fertilizers are recommended from soil analysis. Doses to be applied were defined in the present work, and the amounts of potassium, calcium, magnesium and phosphorus of the organic compost of swine manure were respectively: $1,130 \mathrm{mg} \mathrm{dm}^{-3}, 7 \mathrm{cmol} \mathrm{dm}^{-3}, 5 \mathrm{cmol} \mathrm{dm}^{-3} \mathrm{e} 427 \mathrm{mg} \mathrm{dm}^{-3}$, the nitrogen value was not expressed because the methodology used for compost analysis was the same methodology for soils.

The main function of phosphorus (P) in the plant is to store and transfer energy. It acts in photosynthesis, respiration and various other processes; accelerates root formation, increases grassy tillering along with $\mathrm{N}$, results in greater flowering, and consequently higher grain yield. Its deficiency causes small and unproductive plants. Due to its high retention capacity, although a smaller amount of this nutrient is required, a large application to the soil is required (Instituto Potassa \& Phosfato, 1988; Coelho \& Alves, 2004; Malavolta, 2006).

Potassium (K) is essential for maize production and is absorbed by the plant in larger quantities after N. An average of $30 \%$ of absorbed $\mathrm{K}$ is exported to grains, making production dependent on the use of fertilizers that are a source of this nutrient (Coelho, 2005; Silva \& Hermann, 2013).

The use of swine manure for crop fertilization can contribute to the increase of organic matter and soil fertility level, causing the corn productivity increase, since these residues are rich in nutrients (nitrogen, phosphorus, potassium, copper, sodium, among others) and may be used as an alternative fertilizer to chemical fertilizer (Cavallet al., 2006; Menezes, Berti, Vieira Junior, Ribeiro, \& Berti, 2018).

Comparing the characteristic tables before and after the implementation of the experiment, it is possible to observe that after the experiment the $\mathrm{pH}$ and the effective CTC presented high values (Tables 3 and 4), due to the application of limestone, where it is responsible for the $\mathrm{pH}$ change (increases the value), neutralization of iron and exchangeable aluminum, modifications of the effective cation exchange capacity, among others (Malavolta, 1981).

The higher levels of Phosphorus, Potassium, and Calcium after the experiment implementation (Tables 3 and 4) can be explained due to the chemical characteristics of the organic fertilizer applied to the soil. According to Santos and Camargo (1999), the use of liquid swine manure in the soil increases the availability of all nutrients to plants and alters cation exchange capacity.

Thus, fertilization with organic compost of solid swine manure satisfactorily interfered with desirable characteristics in green corn production. As this was a pioneer work with solid organic compost of waste of swine, it was worked with initial doses, being recommended the study with doses higher than $5 \mathrm{tha}^{-1}$, allowing to obtain an estimate of the doses of maximum production and maximum economic efficiency. Because fertilization with swine waste is an alternative to chemical fertilization, which results in a reduction of environmental pollutants and a reduction in the dependence on external inputs for the farmer. 


\section{Conclusion}

Fertilization with organic compost of solid swine waste up to $5 \mathrm{t} \mathrm{ha}^{-1}$ does not affect the stem diameter of corn plants. The $200 \mathrm{~g} \mathrm{~m}^{-1}\left(2 \mathrm{tha}^{-1}\right)$ dose provided the longest corn cob length. However, the highest dose $\left(500 \mathrm{~g} \mathrm{~m}^{-1}\right.$ or $5 \mathrm{t} \mathrm{ha}^{-1}$ ) increased the height of green corn plants and the weight of corn cob.

Fertilization with swine organic compost increases in soil $\mathrm{P}, \mathrm{K}, \mathrm{Ca}$, even after the corn harvest.

\section{Acknowledgements}

This study was financed in part by the Coordenação de Aperfeiçoamento de Pessoal de Nível Superior-Brasil (CAPES) and published with the financed support of the Programa de Apoio à Publicação de Artigos Científicos of the Fundação de Amparo à Pesquisa do Estado do Amazonas (PAPAC/FAPEAM).

\section{References}

Algeri, A. (2018). Dejetos de aves e suinos no cultivo de hortaliças (Unpublished master's thesis, Universidade Federal do Paraná, Palotina, Brazil). Retrieved from https://acervodigital.ufpr.br/handle/1884/54597

Arruda, M. R., Moreira, A., \& Pereira, J. C. R. (2014). Amostragem e Cuidados na Coleta de Solo para fins de Fertilidade. Manaus, Am: Embrapa Amazônia Ocidental. Retrieved from https://www.infoteca.cnptia. embrapa.br/infoteca/bitstream/doc/1007420/1/Doc115.pdf

Brandão, V. S., Matos, A. T., Martinez, M. A., \& Fontes, M. P. P. (2000). Tratamento de águas residuárias da suinocultura utilizando-se filtros orgânicos. Revista Brasileira de Engenharia Agrícola e Ambiental, 4(3), 327-333. https://doi.org/10.1590/S1415-43662000000300004

Calonego, J. C., Poleto, L. C., Domingues, F. N., \& Tiritan, C. S. (2011). Produtividade e crescimento de milho em diferentes arranjos de plantas. Revista Agrarian, 4(12), 84-90. Retrieved from http://ojs.ufgd.edu.br/ index.php/agrarian/article/view/699/733

Cardoso, B. F., Oyamada, G. C., \& Silva, C. M. (2015). Produção, Tratamento e Uso dos Dejetos Suínos no Brasil. Desenvolvimento em Questão, 13(32), 127-145. https://doi.org/10.21527/2237-6453.2015.32. 127-145

Castoldi, G., Costa, M. S. M., Costa, L. A. M., Pivetta, L. A., \& Steiner, F. (2011). Sistemas de cultivo e uso de diferentes adubos na produção de silagem e grãos de milho. Acta Scientiarum. Agronomy, 33(1), 139-146. https://doi.org/10.4025/actasciagron.v33i1.766

Castro Filho, M. A., Barbosa, M. A. A. F., Oliveira, R. L., Bagaldo, A. R., \& Gastal, D. W. (2007). Valor nutritivo da palha de milho verde para bovinos. Revista Brasileira de Saúde e Produção Animal, 8(2), 112-121. Retrieved from http://revistas.ufba.br/index.php/rbspa/article/view/767/506

Castro, B. B., \& Coelho, F. C. (2014). Produtividade das espigas de milho verde sob adubação química e mineral. Cadernos de Agroecologia, 9(1). Retrieved from http://revistas.aba-agroecologia.org.br/index.php/cad/ article/view/15700

Cavallet, L. E., Lucchesi, L. A. C., Moraes, A., Schimidt, E., Erondi, M. A., \& Fonseca, R. A. (2006). Melhoria da fertilidade do solo decorrentes da adição de água residuária da indústria de enzimas. Revista Brasileira de Engenharia Agrícola e Ambiental, 10, 724-729. https://doi.org/10.1590/S1415-43662006000300027

Cesarino, R. O. (2006). Milho fertirrigado com dejetos líquidos de suínos para ensilagem (Unpublished Master's thesis, Universidade José do Rosário Vellano, Minas Gerais, Brazil). Retrieved from http://tede2.unifenas. br:8080/jspui/handle/jspui/112

Coelho, A. M. (2005). O Potássio na cultura do milho. Piracicaba: Potafos.

Coelho, A. M. (2006). Nutrição e Adubação do Milho. Sete Alagoas, MG: Embrapa. Retrieved from https://www.infoteca.cnptia.embrapa.br/infoteca/bitstream/doc/490410/1/Circ78.pdf

Coelho, A. M., \& Alves, V. M. C. (2004). In T. Yamada \& S. R. S. Abdalla (Eds.), Adubação fosfatada na cultura do milho. Piracicaba, SP: Potafos.

Costa, N. L. (2005). Utilização da soja na alimentação de ruminantes. Retrieved from http//www.agrolink. com.br/colunistas/pg_detalhe_coluna

Dartora, V., Perdomo, C. C., \& Tumelero, I. L. (1998). Manejo de dejetos de suínos. Concórdia, SC: Embrapa Suínos e Aves. Retrieved from http://www.cnpsa.embrapa.br/sgc/sgc_publicacoes/bipers11.pdf 
Ferreira, D. F. (2014). Sisvar: A Guide for its Bootstrap procedures in multiple comparisons. Ciência e Agrotecnologia, 38(2), 109-112. https://doi.org/10.1590/S1413-70542014000200001

Fornasieri Filho, D. (2007). Manual da cultura do milho. Jaboticabal: Funep.

Giacomini, S. J., \& Aita, C. (2008). Cama sobreposta e dejetos líquidos de suínos como fonte de nitrogênio ao milho. Revista Brasileira de Ciência do Solo, 32, 195-205. https://doi.org/10.1590/S0100-06832008000 100019

Grave, R. A., Cassol, P. C., Nicoloso, R. S., Sordi, C., \& Costa, M. D. (2016). Produtividade do milho sob fertilização orgânica a base de dejetos de suínos em diferentes sistemas de preparo do solo. XI Reunião Sul-Brasileira de Ciência do Solo. Retrieved from http://www.sbcs-nrs.org.br/xirsbcs/docs/trab-7-4976352.pdf

Instituto da Potassa \& Fosfato. (1998). Manual internacional de fertilidade do solo. Tradução e adaptação de Alfredo Scheid Lopes. Piracicaba, SP: Potafos. Retrieved from http://brasil.ipni.net/article/BRS-3407

Instituto Nacional de Meteorologia. (2020). Banco de Dados Meteorológicos para Ensino e Pesquisa. Retrieved from http://www.inmet.gov.br/portal/index.php?r=bdmep/bdmep

Kunz, A, Higarashi, M. M., \& Oliveira, P. A. (2005). Tecnologias de manejo e tratamento de dejetos de suínos estudadas no Brasil. Cadernos de Ciência \& Tecnologia, 22(3), 651-665. https://doi.org/10.35977/ 0104-1096.cct2005.v22.8663

Lazia, B. (2012). O que fazer com os dejetos dos suínos. Retrieved from https://www.portalagropecuario.com.br/ suinocultura/o-que-fazer-com-os-dejetos-dos-suinos

Lourenzi, C. R., Ceretta, C. A., Brunetto, G., Girotto, E., Tiecher, T. L., Vieira, R. C. B., ... Ferreira, P. A. A. (2014). Pig slurry and nutrient accumulation and dry matter and grain yield in various crops. Revista Brasileira de Ciência do Solo, 38, 949-958. https://doi.org/10.1590/S0100-06832014000300027

Magalhães, P. C., \& Durães, F. O. M. (2006). Fisiologia da Produção de Milho. Sete Lagões, MG: Embrapa. Retrieved from https://ainfo.cnptia.embrapa.br/digital/bitstream/CNPMS/19620/1/Circ_76.pdf

Malavolta, E. (1981). Manual de Química Agrícola: Adubos e adubação. São Paulo: Agronômica Ceres.

Malavolta, E. (2006). Manual de nutrição mineral de plantas. Piracicaba: Editora Ceres.

Marschner, H. (1995). Mineral nutrition of higher plants. London: Academic Press.

Menezes, J. F. S., Berti, M. P. S., Vieira Junior, V. D., Ribeiro, R. L., \& Berti, C. L. F. (2018). Extração e exportação de nitrogênio, fósforo e potássio pelo milho adubado com dejetos de suínos. Revista de Agricultura Neotropical, 5(3), 55-59. https://doi.org/10.32404/rean.v5i3.1645

Nakano Neto, M., \& Mello, S. P. (2010). Produção de silagens de milho (Zea mays L.) com diferentes adubações. Nucleus, 7(2). https://doi.org/10.3738/nucleus.v7i2.382

Okumura, R. S., Mariano, D. C., \& Zaccheo, P. V. C. (2011). Uso de fertilizante nitrogenado na cultura do milho: uma revisão. Revista Brasileira de Tecnologia Aplicada nas Ciências Agrárias, 4(2), $226-244$. https://doi.org/10.5777/paet.v4i2.1337

Oliveira, F. N. S., Lima, H. J. M., \& Cajazeira, J. P. (2004). Uso da compostagem em sistemas agrícolas orgânicos. Fortaleza, CE: Embrapa Agroindústria Tropical. Retrieved from http://www.infoteca.cnptia. embrapa.br/infoteca/handle/doc/418734.

Oliveira, P. A. V. de. (1993). Manual de manejo e utilização dos dejetos de suínos. Concórdia, SC: Embrapa Suínos e Aves. Retrieved from http://www.infoteca.cnptia.embrapa.br/infoteca/handle/doc/434003

Oliveira, P. A. V. de. (2004). Tecnologias para o manejo de resíduos na produção de suínos: Manual de boas práticas. Concórdia, SC: Embrapa Suínos e Aves. Retrieved from http://www.cnpsa.embrapa.br/sgc/ sgc_publicacoes/publicacao_n3r85f3h.pdf

Pereira Filho, I. A. (2002). O cultivo do milho verde. Sete Lagoas: Embrapa Milho e Sorgo. Retrieved from http://www.infoteca.cnptia.embrapa.br/infoteca/handle/doc/485177

Pra, A. D., Kozen, E. A., Oliveira, P. A., \& Moraes, E. (2005). Compostagem de Dejetos Líquidos de Suínos. Sete Lagoas, MG: EMBRAPA. Retrieved from https://www.embrapa.br/busca-de-publicacoes/-/publicacao/ 489733/compostagem-de-dejetos-liquidos-de-suinos 
Pra, M. A. D., Correa, E. K., Roll, V. F. B., \& Xavier, E. G. (2008). Compostagem de dejetos de suínos. Tecno-Lógica, 12, 28-32. https://doi.org/10.17058/tecnolog.v12i1.289

Ribeiro, J. E. L. S., Júnior, E. M. S. J., Ribeiro, J. E. L. S., Hopkins, M. J. G., Vicentini, A., Sothers, C. A., ... Assunção, P. A. C. L. (1999). Flora da Reserva Ducke: guia de identificação das plantas vasculares de uma floresta de terra-firme na Amazônia Central. Manaus: INPA.

Santos, G. A., \& Camargo, F. A. O. (1999). Fundamentos da matéria orgânica do solo: Ecossistemas tropicais e subtropicais. Porto Alegre, RS: Gênesis.

Scherer, E. E., \& Baldissera, I. T. (1994). Aproveitamento dos dejetos de suínos como fertilizante. In: Dia de campo sobre manejo e utilização de dejetos de suínos. Concórdia, SC: Embrapa Suínos e Aves.

Scherer, E. E., Nesi, C. N., \& Massotti, Z. (2010). Atributos químicos do solo influenciados por sucessivas aplicações de dejetos suínos em áreas agrícolas de Santa Catarina. Revista Brasileira de Ciência do Solo, 34 , 1375-1383. https://doi.org/10.1590/S0100-06832010000400034

Seidel, E. P., Junior, A. C. G., Vanin, J. P., Strey, L., Schwantes, D., \& Nacker, H. (2010). Aplicação de dejetos de suínos na cultura do milho cultivado em sistema de plantio direto. Acta Scientiarum. Technology, 32(2). 113-117. https://doi.org/10.4025/actascitechnol.v32i2.5312

Serafim, R. S., \& Galbiatti, J. A. (2012). Efecto de la aplicación de la agua residual porcina en el pasto Brachiaria brizantha cv Marandu. Revista Colombiana de Ciencia Animal, 4(1), 185-203. https://doi.org/ 10.24188/recia.v4.n1.2012.307

Silva, D. J., \& Queiroz, A. C. (2002). Análise de alimentos: Métodos químicos e biológicos (3rd ed.). Viçosa: UFV.

Silva, J. R. P., \& Hermann, E. R. (2013). Fontes de potássio para a cultura do milho (Zea mays L.). XXXIV Congresso Brasileiro de Ciência do Solo. Retrieved from https://www.sbcs.org.br/cbcs2013/anais/arquivos/ 1919.pdf

Souza, E. da S., Brito, C. F. B., Fonseca, V. A., \& Bebé, F. V. (2016). Crescimento de milho em latossolo com aplicação de água residuária de suinocultura. Enciclopédia Biosfera, 13(23), 369-376. https://doi.org/ 10.18677/Enciclopedia_Biosfera_2016_032

Tavera-Cortés, M. E., Escamilla-García, P. E., \& Pérez-Soto, F. (2018). Impacts on Productivity through Sustainable Fertilization of Nopal (Opuntia Ficus-Indica) Crops Using Organic Compost. Journal of Agricultural Science, 10(4), 297-305. https://doi.org/10.5539/jas.v10n4p297

Weinärtner, M. A., Aldrighi, C. F. S., \& Medeiros, C. A. B. (2006). Práticas Agroecológicas: Adubação Orgânica. Pelotas, SC: Embrapa. Retrieved from http://www.infoteca.cnptia.embrapa.br/infoteca/handle/ doc/903698

\section{Copyrights}

Copyright for this article is retained by the author(s), with first publication rights granted to the journal.

This is an open-access article distributed under the terms and conditions of the Creative Commons Attribution license (http://creativecommons.org/licenses/by/4.0/). 